OPEN ACCESS

Approved by:

Frontiers in Microbiology Editorial

Office,

Frontiers Media SA, Switzerland

*Correspondence: Anderson S. Sant'Ana

and@unicamp.br

Specialty section: This article was submitted to

Food Microbiology,

a section of the journal

Frontiers in Microbiology

Received: 01 November 2018 Accepted: 09 November 2018 Published: 28 November 2018

Citation:

Alvarenga VO, Campagnollo FB, Pia AKR, Conceição DA, Abud Y,

Sant'Anna C, Hubinger MD and Sant'Ana AS (2018) Corrigendum: Quantifying the Responses of Three Bacillus cereus Strains in Isothermal Conditions and During Spray Drying of

Different Carrier Agents.

Front. Microbiol. 9:2876.

doi: 10.3389/fmicb.2018.02876

\section{Corrigendum: Quantifying the Responses of Three Bacillus cereus Strains in Isothermal Conditions and During Spray Drying of Different Carrier Agents}

\author{
Verônica O. Alvarenga ${ }^{1}$, Fernanda B. Campagnollo ${ }^{1}$, Arthur K. R. Pia ${ }^{1}$, \\ Deborah A. Conceição ${ }^{1}$, Yuri Abud ${ }^{2}$, Celso Sant'Anna ${ }^{2}$, Miriam D. Hubinger ${ }^{3}$ and \\ Anderson S. Sant'Ana ${ }^{1 *}$
}

\begin{abstract}
${ }^{1}$ Department of Food Science, Faculty of Food Engineering, University of Campinas, Campinas, Brazil, ${ }^{2}$ Laboratory of Biotechnology (Labio), Metrology Applied to Life Science Division - National Institute of Metrology, Quality and Technology (Inmetro), Duque de Caxias, Brazil, ${ }^{3}$ Department of Food Engineering, Faculty of Food Engineering, University of Campinas,
\end{abstract} Campinas, Brazil

Keywords: spores, low water activity, thermal processing, dried foods, sporeforming bacteria, dairy products, milk, foodborne pathogens

\section{A Corrigendum on}

Quantifying the Responses of Three Bacillus cereus Strains in Isothermal Conditions and During Spray Drying of Different Carrier Agents

by Alvarenga, V. O., Campagnollo, F. B., Pia, A. K. R., Conceição, D. A., Abud, Y., Sant'Anna, C., et al. (2018). Front. Microbiol. 9:1113. doi: 10.3389/fmicb.2018.01113

In the original article, we neglected to include the funder Fundação de Amparo à Pesquisa do Estado de São Paulo (FAPESP), 18/09442-0 to AS. The authors apologize for this error and state that this does not change the scientific conclusions of the article in any way. The original article has been updated.

Conflict of Interest Statement: The authors declare that the research was conducted in the absence of any commercial or financial relationships that could be construed as a potential conflict of interest.

Copyright () 2018 Alvarenga, Campagnollo, Pia, Conceição, Abud, Sant'Anna, Hubinger and Sant'Ana. This is an open-access article distributed under the terms of the Creative Commons Attribution License (CC BY). The use, distribution or reproduction in other forums is permitted, provided the original author(s) and the copyright owner(s) are credited and that the original publication in this journal is cited, in accordance with accepted academic practice. No use, distribution or reproduction is permitted which does not comply with these terms. 